\title{
Effects of feeding level on body weight, hump size, lipid content and adipocyte volume in the dromedary camel
}

\author{
Mohammed BENGOUMI ${ }^{\mathrm{a}}$, Yannick FAULCONNIER ${ }^{\mathrm{b}}$, Ahmed TABARANI $^{\mathrm{c}}$, \\ Abdelmalek SGHIRI ${ }^{\mathrm{c}}$, Bernard FAYE ${ }^{\mathrm{d}}$, Yves CHILLIARD ${ }^{\mathrm{b} *}$ \\ a Institut Agronomique et Vétérinaire Hassan II, BP 6202 Rabat-Instituts, Rabat, Morocco \\ b INRA, Unité de Recherche sur les Herbivores, Theix, 63122 St Genès-Champanelle, France \\ c Direction de l'Élevage, MADR, Rabat, Morocco \\ d CIRAD-EMVT, Campus International de Baillarguet, TA/30A 34398 Montpellier Cedex, France
}

(Received 21 October 2004; accepted 26 May 2005)

\begin{abstract}
In order to study the effect of underfeeding and overfeeding on the fat deposition in the dromedary camel, 14 camels were divided into three groups: an overfed-underfed group (OV-UN), an underfed-overfed group (UN-OV) and a control group (CTRL). After a 4-wk adaptation, a crossover design was applied for 16 weeks including two periods of 8 weeks each. The three energy levels in the diet corresponded to $17 \%(\mathrm{UN}), 68 \%$ (CTRL) and $134 \%(\mathrm{OV})$ of the theoretical maintenance energy requirements. Body weight and barymetric parameters were measured weekly. Hump fat samples were collected monthly for determination of adipocyte size and lipid content. Overfeeding had or tended to have a significant effect on body weight, hump size, hump lipid content and adipocyte volume. Thus, the increase of the hump weight was $71 \%$ in the OV-UN group and $19 \%$ in the UNOV group. Hump fat content increased from 52.9 to $63.6 \%$ in the OV-UN group and from 54.2 to $64.7 \%$ in the UN-OV group. Similarly, trends were observed for the adipocyte volume with an increase from 138 to $253 \mathrm{pL}$ and from 275 to $346 \mathrm{pL}$ in the OV-UN and UN-OV groups, respectively. Underfeeding had reverse effects: the hump weight decreased by $41 \%$ in the OV-UN group and $4 \%$ in the UN-OV group. Similarly, the hump lipid content decreased significantly in the OV-UN group from 63.6 to $53.0 \%$ and not significantly from 58.0 to $54.2 \%$ in the UN-OV group. Underfeeding decreased the adipocyte volume from 253 to $167 \mathrm{pL}$ (OV-UN group) and from 292 to $275 \mathrm{pL}$ (UNOV group). A high significant positive correlation was observed between the hump lipid content and adipocyte volume. Low speed changes in the hump size, volume and lipid content could be linked to the camel adaptation to underfeeding conditions in dry areas.
\end{abstract}

camel / feeding level / hump / adipocyte

Résumé - Effet du niveau d'alimentation sur le poids vif, la taille, la teneur en lipides et le volume des adipocytes de la bosse chez le dromadaire. Les effets de la suralimentation et de la sous-alimentation sur les réserves lipidiques chez le dromadaire ont été mesurés chez 14 chamelles

* Corresponding author: chilliar@ clermont.inra.fr 
divisées en trois lots : un lot suralimenté - sous-alimenté (OV-UN), un lot sous-alimenté suralimenté (UN-OV) et un lot témoin (CTRL). Après 4 semaines d'adaptation un schéma expérimental croisé a été appliqué pendant 16 semaines comprenant 2 périodes de 8 semaines chacune. L'apport énergétique des 3 niveaux d'alimentation représentait 17, 68 et $134 \%$ des besoins énergétiques théoriques d'entretien respectivement pour le régime sous-alimentation, témoin et suralimentation. Le poids vif et les paramètres barymétriques ont été mesurés chaque semaine. Les biopsies de la bosse pour la détermination de la taille des adipocytes et la teneur en lipides ont été réalisées mensuellement. La suralimentation a un effet significatif sur le poids vif, la taille de la bosse et sa teneur en lipides ainsi que sur le volume des adipocytes. Le poids de la bosse augmente de $71 \%$ pour le lot OV-UN et de $19 \%$ pour le lot UN-OV. La teneur en matière grasse augmente de 52,9 à $63,6 \%$ pour le lot OV-UN et de 54,2 à $64,7 \%$ pour le lot UN-OV. Des évolutions similaires sont observées pour le volume des adipocytes qui augmente de 138 à $253 \mathrm{pL}$ et de 275 à $346 \mathrm{pL}$ pour les lots OV-UN et UN-OV, respectivement. La sous-alimentation a un effet inverse avec une diminution du poids de la bosse de $41 \%$ pour le lot OV-UN et de $4 \%$ pour le lot UN-OV. La teneur en lipides de la bosse diminue également significativement de 63,6 à 53,0 \% pour le lot OV-UN et de manière non significative de 58,0 à 54,2 \% pour le lot UN-OV. De même, la sous-alimentation diminue significativement le volume des adipocytes de 253 à 167 et de 292 à 275 pL pour les lots OV-UN et UN-OV, respectivement. Une corrélation hautement significative est observée entre le volume des adipocytes de la bosse et sa teneur en lipides. La faible vitesse de variation de la taille de la bosse, de sa teneur en lipides et de la taille de ses adipocytes sont probablement des particularités liées aux mécanismes d'adaptation du dromadaire à la sous alimentation dans les zones arides.

dromadaire / niveau d'alimentation / bosse / adipocytes

\section{INTRODUCTION}

The camel is well known for its adaptation to dehydration and underfeeding $[3,31$, 32]. The mechanisms of resistance to dehydration, or to mineral deficiency have been studied [4, 14]. Reports concerning the mechanisms of adaptation to the extreme variation of feeding in camels and body fat changes during underfeeding are rare [10, $13,17]$. During underfeeding periods, ruminants use their fat stores to maintain their productivity, and/or to survive, by mobilizing adipose tissue accumulated during overfeeding periods $[8,11]$. Simultaneously to fat mobilization, the camel as for other mammals [11] is probably able to mobilize proteins, particularly visceral and muscular proteins. However, we are not aware of any published data on that subject in camels. In the dromedary camel, the main fat reserves are located in the hump and secondarily around the kidney, mesentery and sternum [18]. Previous studies have demonstrated a positive relationship between the hump and kidney fat weight and their respective adipocyte sizes, and also between the volume of the hump and the body condition score
$[15,16]$. Those studies were performed on camels with an unknown nutritional status. The aim of the present work was to study the effect of different levels of energy intake, especially during overfeeding and underfeeding periods, on hump lipid content and size, adipocyte size and some body measurements in the dromedary camel.

\section{MATERIALS AND METHODS}

\subsection{Animals}

The experiment was carried out at the insemination center of Ain Jemaa (Casablanca, Morocco) from March to August 2000 on fourteen 10 to 15 -year old female camels (Camelus dromedarius).

The animals were treated for external and internal parasites by ivermectine (IVOMEC®) injection during the first day of the adaptation period at the dosage of $0.2 \mathrm{mg}$ per $\mathrm{kg}$ of body weight. They were fed daily with the same control diet including $2 \mathrm{~kg}$ of wheat straw and $0.5 \mathrm{~kg}$ per $100 \mathrm{~kg} \mathrm{BW}$ per day of barley for one month. Water was 
provided ad libitum. After one month, the animals were divided into three groups: overfed-underfed (OV-UN), underfed-overfed (UN-OV) and control (CTRL) groups containing respectively 5,5 and 4 animals. The control group received the basal diet providing $68 \%$ of the maintenance energy requirements as estimated by Wardeh [30]. This basal diet level has been chosen according to the usual feeding practices of the camel herders in Morocco. During the 4-month experimental period, a cross over design was applied to the two other groups. The OV-UN group was overfed with the basal diet and a daily supplement of $0.5 \mathrm{~kg}$ per $100 \mathrm{~kg} \mathrm{BW}$ of barley providing $134 \%$ of the maintenance energy requirements for 2 months and then for another 2 months they were fed a restricted diet with $2 \mathrm{~kg}$ per day of wheat straw, providing $17 \%$ of the maintenance energy requirements. The UN-OV group was fed a restricted diet with $2 \mathrm{~kg}$ per day of wheat straw for 2 months and then they were overfed with the basal diet and a daily supplement of $0.5 \mathrm{~kg}$ per $100 \mathrm{~kg} \mathrm{BW}$ of barley for 2 months.

At the beginning of the experiment (at d7 ), the mean body weights were $383 \pm 33$, $374 \pm 55$ and $340 \pm 39 \mathrm{~kg}$ in the control, UN$\mathrm{OV}$ and $\mathrm{OV}-\mathrm{UN}$ groups, respectively.

\subsection{Body weight and hump measurements}

The animals were weighed weekly in the morning before diet distribution during the experimental period using a dump scale. The measurement of the hump size (length, height, and circumference) was performed weekly according to the method described by Faye et al. [16]. The hump volume (HV) and hump weight (HW) were estimated using the equations:

(1) $\mathrm{HV}=0.07 \mathrm{~L} \times \mathrm{B} \times \mathrm{H}$

(2) $\mathrm{HW}(\mathrm{kg})=0.45 \mathrm{H}(\mathrm{cm})-13.8$

where $\mathrm{L}$ is the length of the hump (half-circumference from the forehead to the back through the top), B is the basal half-circumference of the hump (from the forehead to the back through the base of the hump) and $\mathrm{H}$ is the height of the hump (half-circumference from one side to the other through the top). Formula (1) was calculated considering the hump as a hemi ellipsoid. Formula (2) was calculated $(\varepsilon=0.571, \mathrm{n}=64$, $P<0.001)$ from data at slaughter collected in southern Morocco [22].

\subsection{Biopsies}

Hump biopsies were performed monthly by collecting one $\mathrm{cm}^{3}$ of adipose tissue. The animal was stood and did not receive a general sedative. The skin of the puncture was shaved and disinfected with iodine dye. After a local anaesthesia by subcutaneous injection of $2 \mathrm{~mL}$ of xylocaïne, two small incisions $(2 \mathrm{~cm})$ were carried out. The skin was rolled off and the adipose tissue was collected using slender bistouries. After the biopsy, the wound was disinfected and sutured. The preparation of the adipose tissue for adipocyte size measurements was described in previous studies [23,24]. Briefly, adipose tissue cellularity was measured on tissue fixed with osmium tetroxide and digested in urea solution. Cell diameters $>25 \mu \mathrm{m}$ were measured with Optimas software (Optimas Corporation, Bothell, WA) and the mean volume was calculated from the individual cell volumes. The lipid content of biopsy samples was determined using petroleum ether extraction in a Soxhlet apparatus [1].

\subsection{Statistical analysis}

The results were analyzed using ANOVA on repeated measures for the comparison between and within groups. The Student pairwise $t$ test was used to compare the mean values between phases within groups. Only within-group variations were tested because the analyzed parameters were strongly heterogeneous between the groups at the beginning of the trial. Correlations between parameters were studied using the Pearson method. The software R was used for all the statistical analyses [20]. 


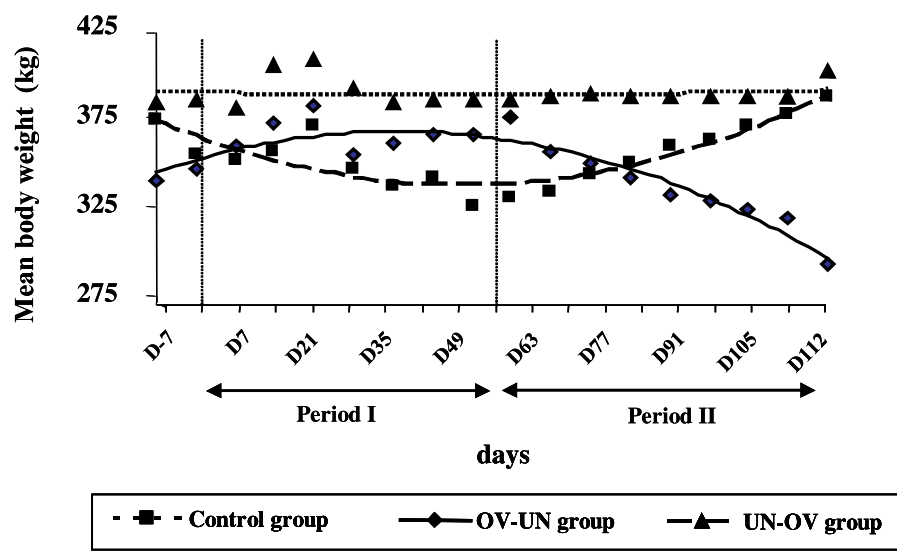

Figure 1. The effect of underfeeding-overfeeding (UN-OV) and overfeeding-underfeeding (OVUN) on the body weight in camels.

\section{RESULTS}

\subsection{Body weight and hump size}

The body weight of some animals increased and decreased weekly according to the "sawtooth waveform". However, the mean trends of the body weight in the OV$\mathrm{UN}$ and UN-OV groups, respectively, were opposite (Fig. 1 and Tab. I). In the control group, the body weight did not vary significantly, despite unexpected variations at the beginning and end of the experiment.

Mean hump dimensions are shown in Figures 2, 3 and 4. In the control group, there was no significant change in the hump dimensions.

Table I. Changes in body weight, hump volume, hump weight, abdomen and chest circumferences in the different groups of camels.

\begin{tabular}{lllll}
\hline Measurements & Groups & & Days & D112 \\
\cline { 3 - 4 } & & \multicolumn{1}{c}{ D0 } & D56 & $292 \pm 53$ \\
\hline Body weight (kg) & OV-UN & $345 \pm 42$ & $374 \pm 39$ & $387 \pm 13$ \\
& UN-OV & $354 \pm 42$ & $329 \pm 17$ & $401 \pm 39$ \\
\hline Hump volume (L) & Control & $384 \pm 27$ & $384 \pm 15$ & $4.49 \pm 1.12$ \\
& OV-UN & $4.81 \pm 1.00$ & $6.66 \pm 0.81$ & $4.76 \pm 0.85$ \\
& UN-OV & $5.49 \pm 0.72$ & $4.08 \pm 0.65$ & $6.28 \pm 1.23$ \\
\hline Hump weight (kg) & Control & $5.96 \pm 1.08$ & $6.21 \pm 1.28$ & $3.12 \pm 1.37$ \\
& OV-UN & $3.12 \pm 1.70$ & $5.32 \pm 1.96$ & $5.55 \pm 2.55$ \\
& UN-OV & $4.83 \pm 2.39$ & $4.65 \pm 2.57$ & $4.88 \pm 1.63$ \\
\hline Abdomen circumference & Control & $3.86 \pm 1.62$ & $4.87 \pm 1.63$ & $229 \pm 12$ \\
(cm) & OV-UN & $220 \pm 11$ & $238 \pm 12$ & $210 \pm 6$ \\
& UN-OV & $215 \pm 7$ & $212 \pm 6$ & $225 \pm 5$ \\
\hline Chest circumference (cm) & Oontrol & $224 \pm 5$ & $225 \pm 5$ & $176 \pm 4$ \\
& OV-UN & $177 \pm 4$ & $180 \pm 4$ & $179 \pm 4$ \\
& UN-OV & $186 \pm 16$ & $182 \pm 13$ & $182 \pm 5$ \\
\hline
\end{tabular}




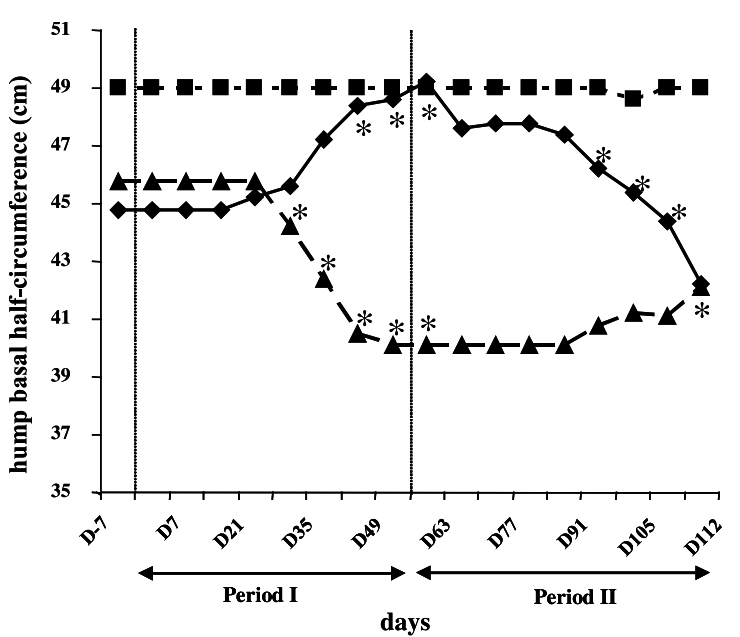

- - - Control group $\longrightarrow$ OV-UN group $\quad-\leftarrow$ UN-OV group

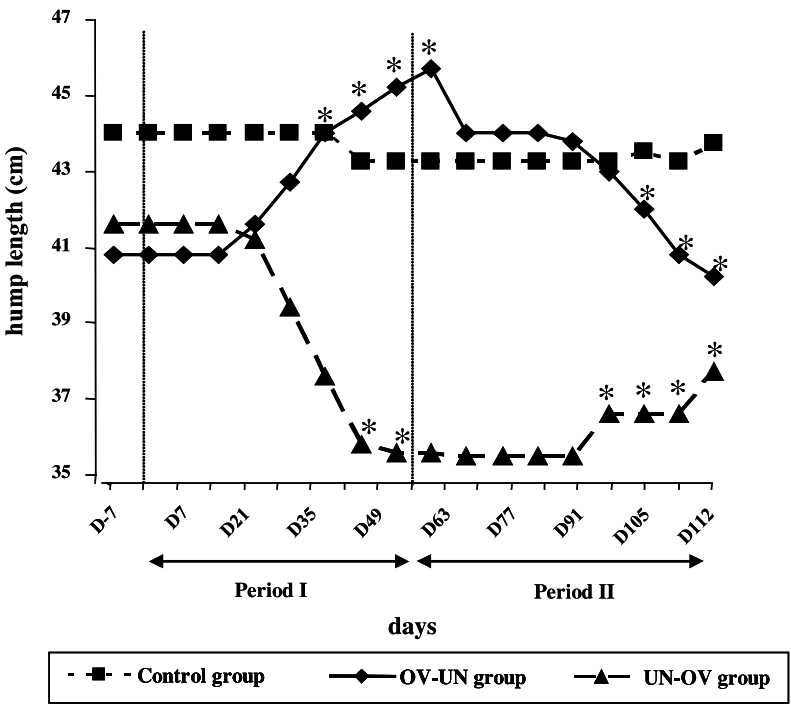

Figure 2. The effect of underfeeding-overfeeding (UN-OV) and overfeeding-underfeeding (OV-UN) on the hump basalhalf circumference in camels (*P<0.05; ** $P<0.01$ ).

Figure 3. The effect of underfeeding-overfeeding (UN-OV) and overfeeding-underfeeding (OV-UN) on the hump length in camels $(* P<0.05 ; * * P<0.01)$.
In the OV-UN group, a significant $(P<$ $0.05)$ increase was found from $\mathrm{d} 35$ for length and from $\mathrm{d} 42$ for circumference and height. Changes from d0 were $+13 \%$ for height, $+12 \%$ for length and $+10 \%$ for circumference. The inversion of the feeding level at d56 induced a significant decrease from d91 for height and circumference and from $\mathrm{d} 98$ for length.

In the UN-OV group, a significant decrease of the size occurred 28 days after the beginning of the trial for the circumference $(-12 \%)$ and 42 days after for the length $(-14 \%)$. The increase of the size after the 


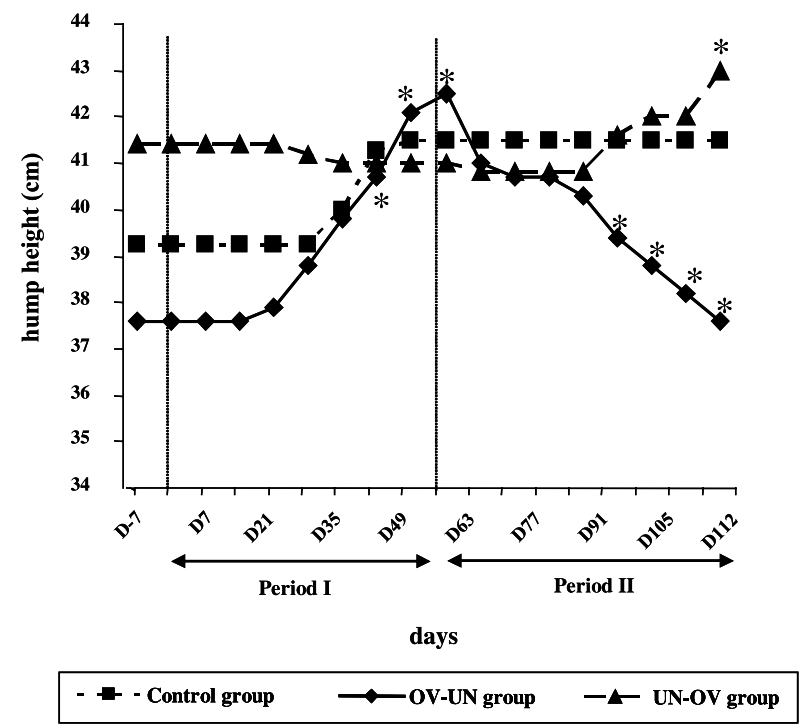

Figure 4. The effect of underfeeding-overfeeding (UN-OV) and overfeeding-underfeeding (OV-UN) on the hump height in camels (* $P<0.05$; ** $P<0.01$ ). overfeeding period was delayed: $\mathrm{d} 112$ for circumference and height and d91 for length.

The hump weight calculated with equation (2) could allow the estimation of the quantity of hump fat that was stored or mobilized during the different periods. The mean hump weight at $\mathrm{d} 0$ was $3.12 \mathrm{~kg}$ in the OV-UN group, $4.83 \mathrm{~kg}$ in the UN-OV group and $3.86 \mathrm{~kg}$ in the control group (Tab. I).

The hump weight gain during the first period ( $\mathrm{d} 0$ to $\mathrm{d} 56)$ was $2.2 \mathrm{~kg}(+71 \%)$ in the OV-UN group while the loss during the second period (d56 to d112) was $2.1 \mathrm{~kg}(-40 \%)$. For the UN-OV group, the loss during the first period was $0.2 \mathrm{~kg}(-4 \%)$ and the gain during the second period was $0.6 \mathrm{~kg}$ $(+14 \%)$. A $1.0 \mathrm{~kg}$ gain was observed in the control group during the first period.

The variations in the hump volume calculated with the equation (1) could allow the estimation of the hump volume that was stored or mobilized during the different periods. The mean value of Table I was $5.42 \mathrm{~L}$, compared with $4.45 \mathrm{~kg}$ for hump weight $(\mathrm{n}=70)$, suggesting an apparent density of 0.82 that could result from the fact that air is comprised within the esti- mated hemi ellipsoid, at least due to the presence of the coat. The mean hump volume at $\mathrm{d} 0$ was $4.81 \mathrm{~L}$ in the $\mathrm{OV}-\mathrm{UN}$ group, $5.49 \mathrm{~L}$ in the UN-OV group and $5.96 \mathrm{~L}$ in the control group (Tab. I).

Hump volume gain during the first period was $+39 \%$ in the OV-UN group while the loss during the second period was $-33 \%$. For the UN-OV group, the loss during the first period was $-26 \%$ and the gain during the second step was $+15 \%$. A gain of $0.33 \mathrm{~L}$ was observed in the control group during the whole 112-d experimental period.

The abdomen and chest circumferences (cm) did not change significantly (Tab. I).

\subsection{Hump lipid content}

The mean hump lipid content varied from 52.9 to $68.0 \mathrm{~g}$ per $100 \mathrm{~g}$ wet tissue. As observed for the hump weight and volume, the hump lipid content increased $(+20 \%$, $P<0.05)$ in the OV-UN group during the overfeeding period and then decreased $(-17 \%$, $P<0.05)$ during the underfed period. In the UN-OV group, the underfeeding did not significantly influence the hump lipid 
Table II. Changes in hump lipid content and adipocyte mean volume in the different groups of camels (* value differs at $P<0.05$ from other values within the same group).

\begin{tabular}{lcccccc}
\hline Measurements & Groups & \multicolumn{5}{c}{ Days } \\
\cline { 3 - 7 } & & D0 & D28 & D56 & D84 & D112 \\
\hline Hump lipid content & OV-UN & $52.9 \pm 6.7$ & $53.9 \pm 4.9$ & $63.6 \pm 8.8 *$ & $55.0 \pm 4.9$ & $53.0 \pm 4.7$ \\
(g per 100 g wet tissue) & UN-OV & $58.0 \pm 8.3$ & $56.2 \pm 7.9$ & $54.2 \pm 8.3$ & $61.6 \pm 10.1$ & $64.7 \pm 9.7$ \\
& Control & $64.0 \pm 5.1$ & $64.4 \pm 3.3$ & $63.7 \pm 4.9$ & $64.7 \pm 4.0$ & $68.0 \pm 3.0$ \\
\hline Adipocyte volume (pL) & OV-UN & $138 \pm 92$ & $159 \pm 96$ & $253 \pm 140 *$ & $160 \pm 48$ & $167 \pm 86$ \\
& UN-OV & $292 \pm 164$ & $275 \pm 185$ & $275 \pm 196$ & $344 \pm 223$ & $346 \pm 226$ \\
& Control & $314 \pm 111$ & $326 \pm 72$ & $298 \pm 104$ & $339 \pm 111$ & $351 \pm 54$ \\
\hline
\end{tabular}

content while the overfeeding induced a nonsignificant increase $(+19 \%)$ of this content. No change was observed in the control group (Tab. II).

According to changes in the hump weight (or volume with a theoretical density of 0.82) and lipid content, the estimated fat mobilization from the hump during the underfeeding period was 1.68 (or 1.55 ) $\mathrm{kg}$ in the OV-UN group and 0.28 (or 0.80 ) $\mathrm{kg}$ in the UN-OV group. The estimated fat storage during the overfeeding period was 1.73 (or 1.41) kg and 0.90 (or 0.68) kg in the OV$\mathrm{UN}$ and the UN-OV groups, respectively.

\subsection{Adipocyte volume}

The initial mean (D0) volume for the OV-UN group was $138 \mathrm{pL}$ which was quite lower than for the UN-OV group (292 pL) and for the control group (314 pL) (Tab. II).

The changes in adipocyte volume showed a significant increase $(+83 \%, P<0.05)$ in the OV-UN group during the overfeeding period and then a decrease $(-34 \%, P<0.05)$ during the underfeeding period.

In the UN-OV group, changes in mean adipocyte volume were in the same way as expected: a decrease $(-6 \%)$ in the underfeeding period and an increase $(+26 \%)$ in the overfeeding period, but these changes were not significant.

In the control group, there was no significant variation in the mean adipocyte volume.
Table III. Pearson correlation matrix between adipocyte volume, hump volume, hump weight and hump lipid rate calculated on 14 animals for 5 samplings ( $\mathrm{n}=70$; $* P<0.05$, ** $P<0.001)$.

\begin{tabular}{lccc}
\hline & $\begin{array}{c}\text { Adipocyte } \\
\text { volume }\end{array}$ & $\begin{array}{c}\text { Hump } \\
\text { volume }\end{array}$ & $\begin{array}{c}\text { Hump } \\
\text { weight }\end{array}$ \\
\hline Adipocyte volume & - & - & - \\
Hump volume & -0.026 & - & - \\
Hump weight & $0.635^{* *}$ & $0.262^{*}$ & - \\
Lipid content & $0.755^{* *}$ & 0.129 & $0.438^{* *}$ \\
\hline
\end{tabular}

\subsection{Relationship between adipocyte volume, hump size and lipid content}

No significant correlation between hump volume and adipocyte volume or hump lipid content was observed (Tab. III). However, significant relationships were observed between hump weight and adipocyte volume $(r=0.635)$, lipid content $(r=0.438)$ or hump volume $(r=0.262)$.

The correlation between hump adipocyte volume and lipid content (independently measured in 2 different laboratories) was highly significant when calculated on 70 biopsied samples (Fig. 5), and also within groups: 0.929 in the OV-UN group, 0.932 in the UN-OV group and 0.864 in the control group $(P<0.001)$. 


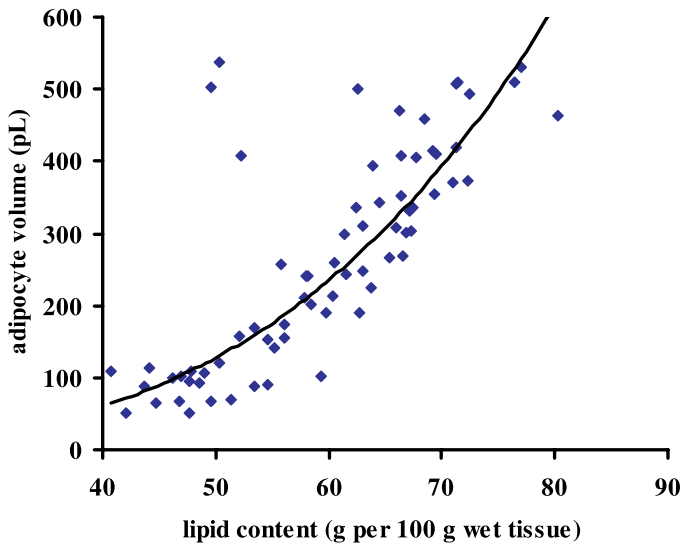

Figure 5. The relationship between adipocyte volume (in $\mathrm{pL}$ ) and lipid content (in \%) in camel hump adipose tissue $(r=0.77$ for the linear adjustment, $y=12.1 \mathrm{x}-453$ and $\mathrm{r}=0.82$ for the non-linear adjustment, $\mathrm{y}=0.0003$ $\left.\mathrm{x}^{3.349} ; \mathrm{n}=70 ; P<0.001\right)$.

\section{DISCUSSION}

\subsection{Body weight, hump size and lipid content}

Most of the camels in our trial had low body weight and hump dimensions in all groups at the beginning of the trial. The mean weight of the animals $(359 \pm 39 \mathrm{~kg})$ at D0 was indeed in the lower part of the range of body weight of the adult Moroccan breeds, which ranged from 280 to $600 \mathrm{~kg}$ according to the breed and body score [2]. In this trial, the estimated hump weight varied from 0.15 to $8.25 \mathrm{~kg}$ while it was 0 to $90 \mathrm{~kg}$ with an average of $18 \mathrm{~kg}$ in the literature. This difference could be related either to the breed [13] or to a poor nutritional status of the animals in the present study.

The proposed diet for the control group covered in theory only $68 \%$ of the requirements in energy. In spite of that hypo-energetic diet, the control group did not show any notable variation of the studied parameters (except for one animal, which presented a significant increase of hump height between $\mathrm{d} 0$ and $\mathrm{d} 56$ ).

Overfeeding induced a significant increase in the body weight. However, the effect of underfeeding seemed to be more significant after an overfeeding period. The apparent random variation of the body weight could be attributed to the irregular water intake. Indeed, the quantity of drinking water could vary extremely in the camel even if the water was available daily ad libitum. Since the camel is adapted to drink great quantities of water, body weight can change suddenly. In spite of the high individual variation, body weight loss during underfeeding was more important in the OV-UN group than in the UN-OV group, suggesting that the effects of previous recent overfeeding could be more rapidly reversed than when the animals were already adapted for a long period to a lower "maintenance" diet.

The decrease of the hump size due to the underfeeding attests to the fat mobilization according to the nature of the hump essentially constituted of adipose tissue. In the camel, the hump represents $44 \%$ of total lipids [18]. The lipid content (wet weight basis) in the hump is over $60 \%$ in adult camels, $64.2 \%$ in less than one-year-olds, $84.8 \%$ in 1 - to 3 -year-olds and $83.1 \%$ in more than 3 -year-olds [21]. These values are higher than the figures attained in this study, which could be attributed to the low body condition of the camels. The lipids in the camel hump, as for the cattle zebu hump or for sheep fat tail, are mobilizable forms of energy to ensure the needs for maintenance, production and adaptation to a harsh environment [10]. This mobilization already 
seemed important after 4 weeks of underfeeding in this study and, conversely, the overfeeding induced an increase of the hump size that was significant after one month. However, the small extent of quantitative changes could indicate that other types of fat depots are implicated, probably the fat around the kidney as suggested in a previous study [16]. Furthermore, this suggests that the mobilization of body reserves during underfeeding occurred at a low rate, reflecting a global adaptation form of the camel to long term energy deficiency.

\subsection{Adipocyte size}

The mean hump adipocyte volume in the three groups at the beginning of the experiment was lower $(248 \mathrm{pL})$ than that reported previously (341 pL) [16]. This difference could be attributed to the high body condition of the animals in that study that were fattened for slaughter. The average of hump adipocytes was lower than that observed in subcutaneous adipose tissue in well-fed cattle and sheep, but similar or higher to that observed in sharply underfed adult cattle [7] and sheep [27].

Overfeeding had a positive effect, especially in the OV-UN group, on the adipocyte size as reported in cattle [7] and sheep [28]. However, a high individual within-group difference was observed, especially in the UN-OV group. This effect was not statistically significant in that group. As discussed in the previous section, the negative effect of underfeeding on the adipocyte volume could be more important after an overfeeding period (OV-UN group), even if this effect was not significant. The small size of the adipocytes at the beginning of the trial could explain the non-significant effect of underfeeding, because lipolysis is more common in fat animals [12].

It generally takes a long time after a change in feeding levels of ruminants to observe any significant change in adipocyte size. For example, it was observed [29] that after 4 months of an experiment in growing cattle a difference occurred between 1.74 and $0.76 \times$ maintenance levels, but not with $1.43 \times$ maintenance. In adult sheep, no difference was observed after 2 weeks at either 0.22 or $1.90 \times$ maintenance [5]. Thus, the 2-month duration of the periods in the present trial could be too short to allow observing fully potential changes in adipocyte volume.

\subsection{Correlations between parameters}

The absence of correlation between calculated hump volume and either lipid content or adipocyte volume could be partly attributed to the uncertainty in the hump volume calculation, especially when the hump was small. Indeed, the volume of the hump was estimated in considering its shape as a hemi-ellipsoid [16]. With small humps, this hypothesis could be debatable. On the contrary, the hump weight of live animals was estimated simply from the height (easier to measure) and using an equation calibrated in the slaughterhouse with a good precision [22]. However, the hump volume gave quantitative estimations of hump changes (Tab. I) that were more stable when comparing a given feeding level for the three groups, probably because the use of 3 independent dimensions was more robust than only one dimension.

The mean adipocyte volume was closely associated to the hump weight (or height) and, more markedly, to the hump lipid content $(r=0.82$ for the non-linear adjustment of the sigmoid curve, Fig. 5). In other ruminants, adipocyte size was related to the total body lipids of the animals, in cattle [9, 25] and sheep [6]. Indeed, the growth of adipose tissue in the adult ruminant was essentially due to the accumulation of lipids in adipocyte vacuoles. Thus, the volume of adipose tissue is related to the change in the size of adipocytes [19, 26].

In conclusion, fat mobilization during underfeeding of low body condition camels was of limited extent, suggesting an adaptation of this species to energy deprivation 
by decreasing the energy expenses. In other respects, the results confirm that in the camel changes in the fat storage level are insured, at least in part, by changes in the volume of hump adipocytes, which result in simultaneous changes in the hump lipid content. Since the hump is the main fat storage in the camel, estimations of its weight and lipid content could be used as good indicators of adiposity in this animal species.

\section{ACKNOWLEDGEMENTS}

This study was achieved in the frame of the PRAD project (No. 01/04) supported by FrenchMoroccan cooperation. The authors thank especially Dr. A. Touré, S. Grech and A. Marouane for their contribution and D. Bany for adipocyte volume measurements.

\section{REFERENCES}

[1] AOAC, Official methods of analysis (15th ed.), Association of Official Analytical chemists, Washington DC, 1989.

[2] Achaabane M.R., Ouassat M., Études et recherches appliquées sur l'élevage camelin, Rapport annuel $\mathrm{n}^{\circ}$ 2, IAV Hassan II, Rabat, Morocco, 1994, 2 p.

[3] Bengoumi M., Riad F., Giry J., De La Farge F., Davicco M.J., Safwate A., Barlet JP., Hormonal control of water and sodium in plasma and urine of camels during dehydration and rehydration, Gen. Comp. Endocrinol. 89 (1993) 378-386.

[4] Bengoumi M., Faye B., Adaptation du dromadaire à la déshydratation, Revue Sécheresse 13 (2102) 121-129.

[5] Bocquier F., Bonnet M., Faulconnier Y., Guerre-Millo M., Martin P., Chilliard Y., Effects of photoperiod and feeding level on adipose tissue metabolic activity and leptin synthesis in the ovariectomized ewe, Reprod. Nutr. Dev. 38 (1998) 489-498.

[6] Bocquier F., Guillouet Ph., Barillet F., Chilliard Y., Comparison of three methods for the in vivo estimation of body composition in dairy ewes, Ann. Zootech. 48 (1999) 297 308.

[7] Chilliard Y., Robelin J., Activité lipoprotéinelipasique de différents dépots adipeux et ses relations avec la taille des adipocytes chez la vache tarie, au cours d'engraissement ou en début de lactation, Reprod. Nutr. Dev. 25 (1985) 287-293.

[8] Chilliard Y., Revue bibliographique. Variations quantitatives et métabolisme des lipides dans le tissu adipeux et le foie au cours du cycle gestation-lactation chez la brebis et la vache, Reprod. Nutr. Dev. 26 (1987) 327398.

[9] Chilliard Y., Rémond B., Agabriel J., Robelin J., Vérité R., Variations du contenu digestif et des réserves corporelles au cours du cycle gestation lactation, Bull. Tech. CRZV Theix 70 (1987) 117-131.

[10] Chilliard Y., Particularités du métabolisme des lipides et du métabolisme énergétique chez le dromadaire, Options méditerranéennes, série séminaires $\mathrm{n}^{\circ} 2$ (1989) 101-110.

[11] Chilliard Y., Bocquier F., Doreau M., Digestive and metabolic adaptation of ruminants on undernutrition and consequences on reproduction, Reprod. Nutr. Dev. 38 (1998) 131152.

[12] Chilliard Y., Ferlay A., Faulconnier Y., Bonnet M., Rouel J., Bocquier F., Adipose tissue metabolism and its role in adaptations to undernutrition in ruminants, Proc. Nutr. Soc. 59 (2000) 127-134.

[13] Faye B., Le guide de l'élevage du dromadaire, Sanofi ed., Libourne, France, 1997, 126 p.

[14] Faye B., Bengoumi M., Le dromadaire face à la sous-nutrition minérale: un aspect méconnu de son adaptabilité aux conditions désertiques, Revue Sécheresse 11 (2000) 155-161.

[15] Faye B., Bengoumi M., Viateau E., Tourret M., Chilliard Y., Adipocyte patterns of adipose tissue in camel hump and kidney, J. Camel Pract. Res. 8 (2001) 29-33.

[16] Faye B., Bengoumi M., Messad S., Chilliard Y., Estimation des réserves corporelles chez le dromadaire, Rev. Élev. Méd. Vét. Pays Trop. 55 (2002) 69-78.

[17] Guerouali A., Wardeh M.F., Assessing nutrients requirements and limits to production of the camel under simulated natural environment, Camel Newsletter 15 (1998) 32-42.

[18] Hidane K., Moujjani Z., Zardoune M., Karib H., Bengoumi M., Camel meat quality. Advance course: Improvement of camel production, CIHEAM-IAV Hassan II, Rabat, Morocco, 2002, 45 p.

[19] Hood R.L., Relationship among growth, adipose cell size and lipid metabolism in ruminant adipose tissue, Fed. Proc. 41 (1982) 2555-2561. 
[20] Ihaka R., Genleman R., A language for data analysis and graphics, J. Comput. Graph. 5 (1996) 299-314.

[21] Kadim I.T., Mahgoub O., Al-Maqbaly R.S., Annamalai K., Al-Ajmi D.S., Effects of age on fatty acid composition of the hump and abdomen depot fats of the arabian camel (Camelus dromedarius), Meat Sci. 62 (2002) 245-251.

[22] Kamili A., Étude de la relation entre certaines mesures barymétriques, le poids vif et le poids de la bosse et de certains organes chez le dromadaire, Thèse Méd. Vét., IAV Hassan II, Rabat, Morocco, 2003, 134 p.

[23] Robelin J., Cellularity of bovine adipose tissues: developmental changes from 15 to 65 percent mature weight, J. Lipid. Res. 22 (1981) 452-457.

[24] Robelin J., Agabriel J., Estimation de l'état d'engraissement des bovins vivants et de la taille des cellules adipeuses, Bull. Tech. CRZV Theix 66 (1986) 34-41.

[25] Robelin J., Chilliard Y., Agabriel J., Estimation of body lipids and proteins of Holstein Charolaise and Limousine cows by dilution technique and adipose cell size, in: Van der Honing Y., Close W.H. (Eds.), Proceedings of the 11th Symposium Energy Metabolism of Farm Animals, EAAP Publication, Pudoc, Wageningen, 1989, Vol. 43, pp. 370-373.
[26] Robelin J., Casteilla L., Différenciation, croissance et développement du tissu adipeux, INRA Prod. Anim. 3 (1990) 243-252.

[27] Sebastian I., Chilliard Y., Jaime C., Purroy A., Variations du volume des adipocytes et de la note d'état corporel chez la brebis Rasa Aragonesa pendant la lactation et après le tarissement, Ann. Zootech. 38 (1989) 83-90.

[28] Sebastian I., Chilliard Y., Purroy A., Jaime C., Supplémentation en céréales, état corporel et enzymes lipogéniques du tissu adipeux chez la brebis Aragonesa, Ann. Zootech. 42 (1993) 299-313.

[29] Smith S.B., Prior R.L., Koong L.J., Mersmann H.J., Nitrogen and lipid metabolism in heifers fed at increasing levels of intake, J. Anim. Sci. 70 (1992) 152-160.

[30] Wardeh M.F., The nutrients requirements of the dromedary camels, The camel applied research and development network, CARDN/ ACSAD/CAMEL/p29/1997, Damascus (Syria), 1997, $97 \mathrm{p}$

[31] Wilson R.T., Ecophysiology of the camelidae and desert ruminants, Springer Verlag, Berlin, $1989,120 \mathrm{p}$.

[32] Yagil R., The desert camel: comparative physiological adaptation, in: Karger (Ed.), Comparative animal nutrition, Basel, 1985, 163 p. 